\title{
Desert Dwelling Trees: Forage Suitability and Ethnobotany, Pakistan

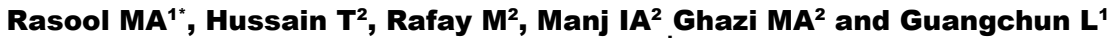 \\ ${ }^{1}$ School of Nature Conservation, Beijing Forestry University, China \\ ${ }^{2}$ The Department of Forestry, Range and Wildlife Management, The Islamia University Of Bahawalpur, Pakistan
}

\begin{abstract}
Phytochemicals are primary and secondary compounds naturally occurring in the plants and trees that have defensive and protection mechanism from various diseases. Plant chemistry has been an integral component for man service as evident from history, providing substantial, entho-botanical and chemical remedies for locals in any subject area. The phyto-chemical profile of five desert dwelling tree species i.e. Salvadora oleides, Acacia nilotica, Prosopis cineraria, Tamarix aphylla and Ziziphus mauritiana was analyzed in Cholistan desert, Punjab, Pakistan. Photochemical analysis of air dried leaves/twigs powder confirmed the presence of alkaloids, flavonoids and saponins but no steroids during extraction. Moreover Chemical analyses revealed that crude fiber (CF) content was $16.67 \%$ and $6.67 \%$ in Prosopis cineraria and Acacia nilotica respectively, crude protein was found highest $(2.62 \%)$ in Zizyphus mauritiana, slightly lower in Salvadora oleoides (2.36\%) and minimum in Acacia nilotica (1.43\%). Salvadora oleioides had highest (41.67\%) ash content, while minimum in Prosopis cineraria (8\%). Fat content (EE) was limiting as $5.33 \%$ in Acacia nilotica and lowest value in Salvadova oleoides (2.33\%). Whereas, nitrogen free extract (NFE) was found maximum in Zizyphus mauritiana (72.22\%). Results revealed species have high nutritional and medicinal values for livestock and local people.
\end{abstract}

Keywords: Phytochemicals; Chemical remedies; Desert dwelling trees; Nutrition values

\section{Introduction}

Phytochemicals are plant-derived chemicals that are not only essential nutrients but known to have protective or disease preventive properties [1]. Plants abundant in these chemicals play a substantial role in the prevention from microbial, insecticidal or herbivorous predation [2]. Plants and plant products are being used as medicine from the ancient time. As estimated by the World Health Organization, approximately $75-80 \%$ of the world's population uses plant medicines either partly or entirely as medicine. Interest in plant derived drug increases mainly due to the increasing use and misuse of existing antibiotics which increases the development of resistance in microbes. This poses the need for search and development of new and effective drugs to cure diseases [3].

Secondary metabolites like alkaloids, flavonoids, terpenoids, tannins, phenols and glycosides contain antimicrobial, anthelmintic, anti-diarrhoeal activities while saponins and polypeptides are considered to contain anticancer and antiviral activities respectively $[2,4,5]$. These metabolites present in fruits and herbs may also protect human from a range of diseases [6]. Water-soluble flavonoid-glycosides and phenolics have been isolated from the plants [7]. Flavonoid-glycosides have shown to possess analgesic and anti-inflammatory activity.

Plants are an essential component for life in the universe. After various observations and experimentations many plants were identified as source of important medicine [8]. Medicinal plants have been used since prehistoric period for the cure of various diseases. Since these are commonly used by the local people and are of great importance that's why a lot of people are engaged in the trade of important medicinal herbs throughout the world. Especially, people living in villages have been commonly using indigenous plants as medicines [9].

Western Thar Desert is rich in varieties of plants. Prosopis cineraria, a member of the family Leguminosae is one of boon plants of Western Rajasthan that provide valuable natural resources to the people. It is native to arid portion of Western and South Asia. Prosopis cineraria are one of the highly valued plants in the Indigenous System of Medicine. It is also known to possess anthelmintic, antibacterial, antifungal, antiviral, anticancer and several other pharmacological properties [10].
Tamaricaceae is relatively a small family of 4 genera and 120 species [11] whereas Tamarix is the largest genus of the family with approximately 50 species wide spread throughout the world. A few species of Tamarix are employed in traditional medicine in Asia and Africa [12]. They are used as astringent, aperitif, stimulus of perspiration and diuretic. It has a variety of names including Salt cedar (English), Farash (India), Tamaris (French), Tamariske (German), Taray (Spanish) and Woestyn tamarisk (Afrikaans). Extract from leaves of the plant is used to treat toothache [13]. Tamarix aphylla is traditionally used for the treatment of rheumatism [14]. The aerial parts of Tamarix species are used for treatment of chronic diseases such as diarrhea and dysentery while the bark is used as an astringent tonic [15]. A decoction of this plant is observed to possess antinociceptive activity and roots have antinociceptive, cytotoxic and diuretic properties [16].

Prosopis cineraria (Linn) is a medium to large sized tree, belonging to the family Mimosaceae. This plant is used in pregnancy as a safeguard against miscarriage. The smoke of the leaves is good for eye troubles. The bark is used as a remedy for rheumatism, cough, common cold, asthma and scorpion stings [17]. Different parts of the plant are useful for the treatment of many diseases like skin diseases, piles, worms, vertigo and dyspnoea [18], protection from miscarriage, Eye diseases, Snake bite, asthma, bronchitis, dysentery, leucoderma, leprosy, muscle tremors and piles [19]. Prosopis sp. has been reported to contain levels of antinutrients such as tannins, known to affect the availability of nutrients by formation of soluble and insoluble complexes. Their effects on the digestibility of nutrients will vary depending on tannin content and astringency [20].

*Corresponding author: Rasool MA, Wetland Ecology La, School of Nature Conservation, Beijing Forestry University, WuDaoKou, Haidian Qu, China, Tel: 008613121893811; E-mail: moosa33381@gmail.com

Received July 20, 2017; Accepted August 22, 2017; Published August 08, 2017

Citation: Hussain T, Rafay M, Manj IA, Ghazi MA, Rasool MA, et al. (2017) Desert Dwelling Trees: Forage Suitability and Ethnobotany, Pakistan. J Biodivers Endanger Species 5: 194. doi: 10.4172/2332-2543.1000194

Copyright: $\odot 2017$ Hussain T, et al. This is an open-access article distributed under the terms of the Creative Commons Attribution License, which permits unrestricted use, distribution, and reproduction in any medium, provided the original author and source are credited. 
Salvadora oleoides locally known as 'Jal' is evergreen small tree, grows in habitats having medium to fine textured soil, belongs to family Salvadoraceae. The fruit of this plant is edible and liked very much by the local inhabitants [21]. S. oleoides is a salt tolerant tree [22,23] with low economic value but it has applications in multiple fields i.e., provides sweet and edible fruits, fodder, fuel, timber and has pharmaceutical value. S. oleoides improves the soil quality, stabilizes the fragile arid area, and provides shelter to livestock and wildlife [24]. Salvadora oleoides, Peelon (dried fruit) is used to treat rheumatism in animals. Dried fruit is given to animals after parturition during winter to facilitate the expulsion of lochia [22].

Z. mauritiana belongs to the family Rhamnaceae, locally known as jujuba or beri, with two major domesticated species, Z. mauritiana and $Z$. jujuba. These two Species have been cultivated over vast areas of the Old World. Fruit are iron tonic and digestive. The plant is used as folk lore especially for goat. Branches are used in fencing. Leaves of this plant especially young leaves are used by the diabetes patient [25]

Acacia nilotica (Family-Mimosaceae) is a medium size thorny tree found in the drier parts of India. The powdered bark of the plant with little salt is used for treating acute diarrhea. The bark is also used extensively for colds, bronchitis, diarrhea, bleeding piles and leucoderma [26]. The tender twigs are used as tooth brushes. The powdered bark of the plant with little salt is used for treating acute diarrhea [27]. The Egyptians believe that diabetics may eat carbohydrates as much as they want if they consume powdered pods of A. nilotica [28]. Polyphenols decrease the blood glucose levels [29]. Supplementation of $A$. nilotica (proanthocyanidins) is reported to be a potentially powerful nutritional approach for management of cardiovascular disease risk in individuals with both metabolic syndrome and elevated low density lipoprotein cholesterol [30].

Various screening methods have been used to assess these compounds through extraction in solvents with similar polarity [31]. Decoctions from different parts of a plant usually contain diverse mixture of phytochemicals [2]. Variability in the concentrations of these extracted substances depends upon the choice of plant part, the extraction procedure and the extractant used [31-33]. Mainly the solvent employed in such studies accounts for the complexity and diversity of the compounds being extracted [34]. This paper is an attempt to identify, isolate and quantify each phytochemical compound present in desert dwelling tree species which are primary source of food and medication for both human race and livestock of the Cholistan desert.

\section{Materials and Methods}

\section{Study area}

The world's seventh largest desert "Cholistan" extends toward India from the southern boundary of Punjab, Pakistan comprising $26,000 \mathrm{~km}^{2}$ area lies among $27^{\circ} 42^{\prime}$ to $29^{\circ} 45^{\prime}$ North and $69^{\circ} 52^{\prime}$ to $75^{\circ} 24^{\prime}$ East [35] with $112 \mathrm{~m}$ altitude (Figure 1) [36]. The desert is sub-divided into two distinct regions: the Lesser Cholistan and the Greater Cholistan covering about $7770 \mathrm{~km}^{2}$ and $18,130 \mathrm{~km}^{2}$ respectively contain negligible amounts of organic matter. Soils of interdunal flats vary in structure, texture, surface, the amount of sodicity and salinity with $\mathrm{pH}$ range from 8.2 to 9.6 [37]. The climate of Cholistan desert is harsh, hot, arid and sub-tropical and influenced by seasonal monsoons. Annual and still daily temperature varies greatly. Winter temperature varies from 15 to $30^{\circ} \mathrm{C}$ while 35 to $50^{\circ} \mathrm{C}$ in the months of May-June [35]. Annual rainfall is low, ranging from $100-250 \mathrm{~mm}$, with its maxima during January to March in winters and July to September during monsoons [38].The
Xeromorphic species found in Cholistan vegetation are adapted to a diversity of environmental stressors, particularly to low nutrients high salinity, aridity, and high temperature fluctuations.

\section{Methods}

Extraction: Uniform dry powder of air dried leaves using four solvents: ethanol (70\%), methanol (70\%), acetone (70\%) and distilled water, was used to have extracts. For each solvent, $100 \mathrm{~g}$ dry powder was extracted with $1000 \mathrm{ml}$ solvent by maceration at room temperature for 48 hours. Then two filtrations of each mixture through $\mathrm{N}^{\circ} 1$ Whatman paper and filter paper $(0.45 \mathrm{Fm}$ porosity) were done. The collected filtrates were dried separately at $50^{\circ} \mathrm{C}$ using a Laborota 4000 rotary evaporator. The residue of each solvent extract was dissolved in water frozen and lyophilized (CHRIST-ALPHA 1-4Lyophilizator). Aqueous acetone, aqueous methanol and aqueous ethanol were air dried to extract crude powder to investigate phytochemical compounds, total phenol content and for antioxidant screening.

\section{Phytochemical analysis}

Tests for alkaloids: Methanol extract $(2 \mathrm{ml}), 1 \mathrm{ml}$ hydrochloric acid and 6 drops of Wagner's reagent were taken in a test tube. The brownish-red precipitates confirmed the alkaloids in extract. In another test tube, $2 \mathrm{ml}$ of $\mathrm{MeOH}$ was taken and 6 drops of Dragnedrff's reagent was added to it. The appearance of yellow precipitates indicated the presence of alkaloids. Analysis was done following Suthar Singh et al. [39].

Test for saponins: In a test tube $0.5 \mathrm{ml}$ water, $1 \mathrm{ml}$ glacial acetic acid, $3 \mathrm{ml} \mathrm{FeCl}_{3}$ soln. and $3 \mathrm{ml}$ conc. $\mathrm{H}_{2} \mathrm{SO}_{4}$ were taken. Greenish-blue color indicated the presence of saponins. Analysis was done following Khan et al. [25].

Test of steroids: $\mathrm{In}$ a test tube, $1 \mathrm{ml}$ chloroform, $2 \mathrm{ml}$ acetic anhydride and $1 \mathrm{ml}$ conc. $\mathrm{H}_{2} \mathrm{SO}_{4}$ were added. No Bluish-green ring formation indicated the absence of steroids.

Test of flavanoid: In a test tube $2 \mathrm{ml}$ methanol, $5 \mathrm{ml}$ conc. $\mathrm{HCl}$ and $0.5 \mathrm{mg} \mathrm{Mg}$ ribbon were added. Pinkish tomato red color indicated the presence of flavanoid. Analysis was done.

\section{Results and Discussion}

\section{Results}

The presence of three chemical compounds (Alkaloids, Flavonoids and Saponins) was confirmed in the leaves of five desert dwelling tree species i.e. Tamarix aphylla, Acacia nilotica, Zyziphus mauritiana, Salvadora oleiodes and Prosopis cineraria, during this study.

Minimum alkaloid concentration was prevalent as $3.2 \%$ in Tamarix aphylla while 9.4\% in Salvadora oleiodes and Prosopis cineraria each at its maximum for these five tree species. Whereas Acacia nilotica showed $5.6 \%$ and Zyziphus mauritiana had $3.5 \%$ alkaloids. Concentration of flavonoids ranged $4.6 \%$ to $28 \%$ among these species. Maximum concentration of flavonoids was sorted in Acacia nilotica (28\%) followed by Tamarix aphylla (14.6\%), Zyziphus mauritiana (12.5\%), Prosopis cineraria (4.9\%) and 4.6\% in Salvadora oleiodes. Saponin's composition varied from $1.43 \%$ to $3.65 \%$. Prosopis cineraria $(3.65 \%)$ are a species that had highest percentage value of saponin. Concentration of saponin in Acacia nilotica was $2.6 \%$ followed by Tamarix aphylla (2.4\%), Zyziphus mauritiana (1.8\%) and lowest in Salvadora oleiodes (1.43\%) (Table 1).

Taking into account the nitrogen free extract (NFE), the highest value for this content was present in Zyziphus mauritiana (72.22\%) followed by Acacia nilotica (71.9\%), Prosopis cineraria (70.2\%), Tamarix 
Citation: Hussain T, Rafay M, Manj IA, Ghazi MA, Rasool MA, et al. (2017) Desert Dwelling Trees: Forage Suitability and Ethnobotany, Pakistan. J Biodivers Endanger Species 5: 194. doi: 10.4172/2332-2543.1000194

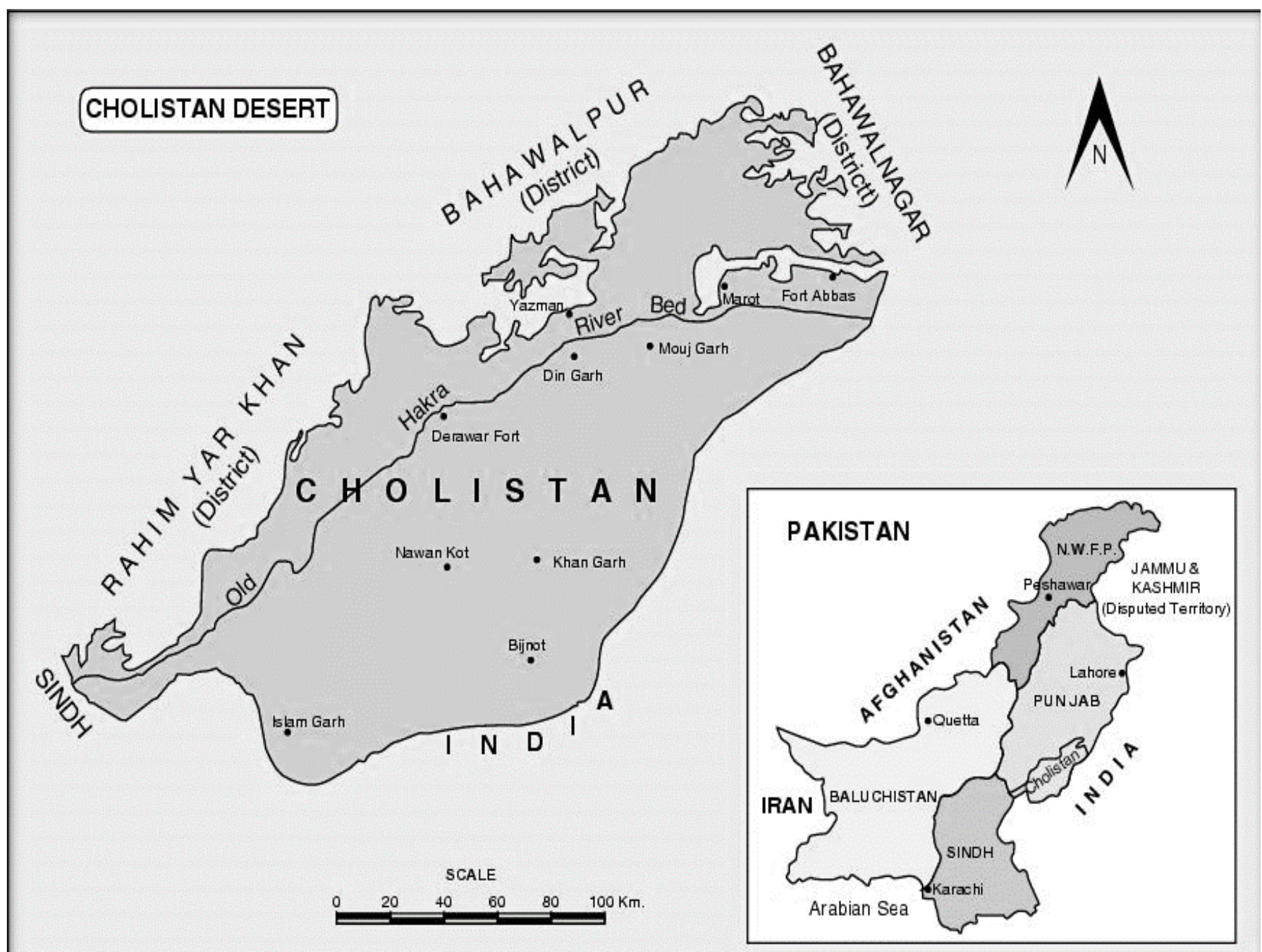

Figure 1: Map of Cholistan desert.

\begin{tabular}{|c|c|c|c|c|}
\hline Sr. No & Species Name & Alkaloids (\%) & Flavonoids (\%) & Saponins (\%) \\
\hline 1 & Salvadora oleiodes & $9.4 \pm 0.7$ & $4.6 \pm 0.5$ & $1.43 \pm 0.2$ \\
\hline 2 & Acacia nilotica & $5.6 \pm 0.8$ & $28 \pm 0.2$ & $2.6 \pm 0.4$ \\
\hline 3 & Prosopis cineraria & $9.4 \pm 0.4$ & $4.9 \pm 0.5$ & $3.65 \pm 0.3$ \\
\hline 4 & Tamarix aphylla & $3.2 \pm 0.2$ & $14.6 \pm 0.7$ & $2.4 \pm 0.3$ \\
\hline 5 & Zyziphus mauritiana & $3.5 \pm 0.6$ & $12.5 \pm 0.3$ & $1.8 \pm 0.5$ \\
\hline
\end{tabular}

The values are the mean \pm SD of triplicate experiments.

Table 1: Phytochemical profile of subject species.

aphylla (62.12\%) and Salvadora oloeides (45.31\%). Average value was of NFA was calculated as $64.35 \%$ for these desert dwelling tree species (Table 2 and Figure 2).

Proximate analysis for EE (Ether Extract), CF (Crude Fiber), CA (Crude Ash), CP (Crude Protein) and NFE (Nitrogen Free Extract) of these five tree species from Cholistan desert explain that the EE ranged from $2.33 \%$ (Salvadora oleides) to $5.33 \%$ (Acacia nilotica) at its maximum with mean value as $3.53 \%$ while Zyziphus mauritiana (4.16\%), Prosopis

\begin{tabular}{|c|c|c|c|c|c|}
\hline Species Name & EE & CF & CP & CA & NFE \\
\hline Salvadora oleides & 2.33 & 8.33 & 2.36 & 41.67 & 45.31 \\
\hline Acacia nilotica & 5.33 & 6.67 & 1.43 & 14.67 & 71.9 \\
\hline Prosopis cineraria & 2.92 & 16.67 & 2.21 & 8 & 70.2 \\
\hline Tamarix aphylla & 2.91 & 13.67 & 2.3 & 19 & 62.12 \\
\hline Zyziphus mauritiana & 4.16 & 9 & 2.62 & 12 & 72.22 \\
\hline Mean & 3.53 & 10.868 & 2.184 & 19.068 & 64.35 \\
\hline SEM $^{*}$ & 0.31326 & 1.0595 & 0.11012 & 3.181 & \\
\hline
\end{tabular}

Key: Mean tree species does not differ significantly at $p>0.05$. "SEM: Standard Error of mean; Mean values based on three replicates

Table 2: Proximate nutritional composition

cineraria $(2.92 \%)$ and Tamarix aphylla had $2.91 \%$. The CF was highest in Prosopis cineraria (16.67\%) followed by $13.67 \%$ (Tamarix aphylla), 9\% (Zyziphus mauritiana), 8.33\% (Salvadora oleiodes), and lowest was in Acacia nilotica (6.67\%) having mean value of $10.868 \%$. Contents of CP varied from $2.62 \%$ in Zyziphus mauritiana at its maximum and gradually decreased in Salvadora oleiodes (2.36\%), Tamarix aphylla 
Citation: Hussain T, Rafay M, Manj IA, Ghazi MA, Rasool MA, et al. (2017) Desert Dwelling Trees: Forage Suitability and Ethnobotany, Pakistan. J Biodivers Endanger Species 5: 194. doi: 10.4172/2332-2543.1000194

\section{Nitrogen Free Extract}

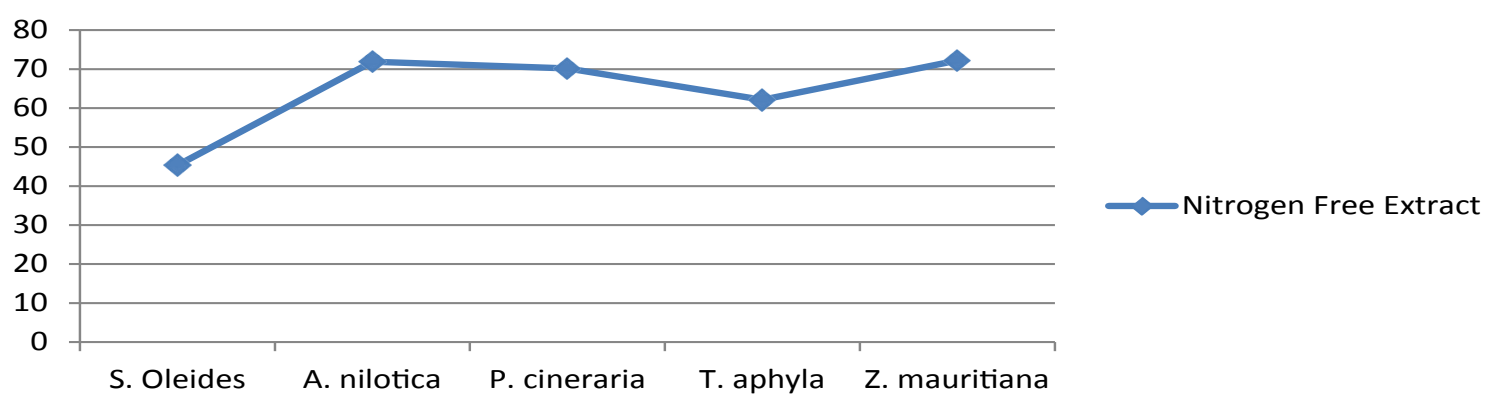

Figure 2: Nitrogen free extract of target species.

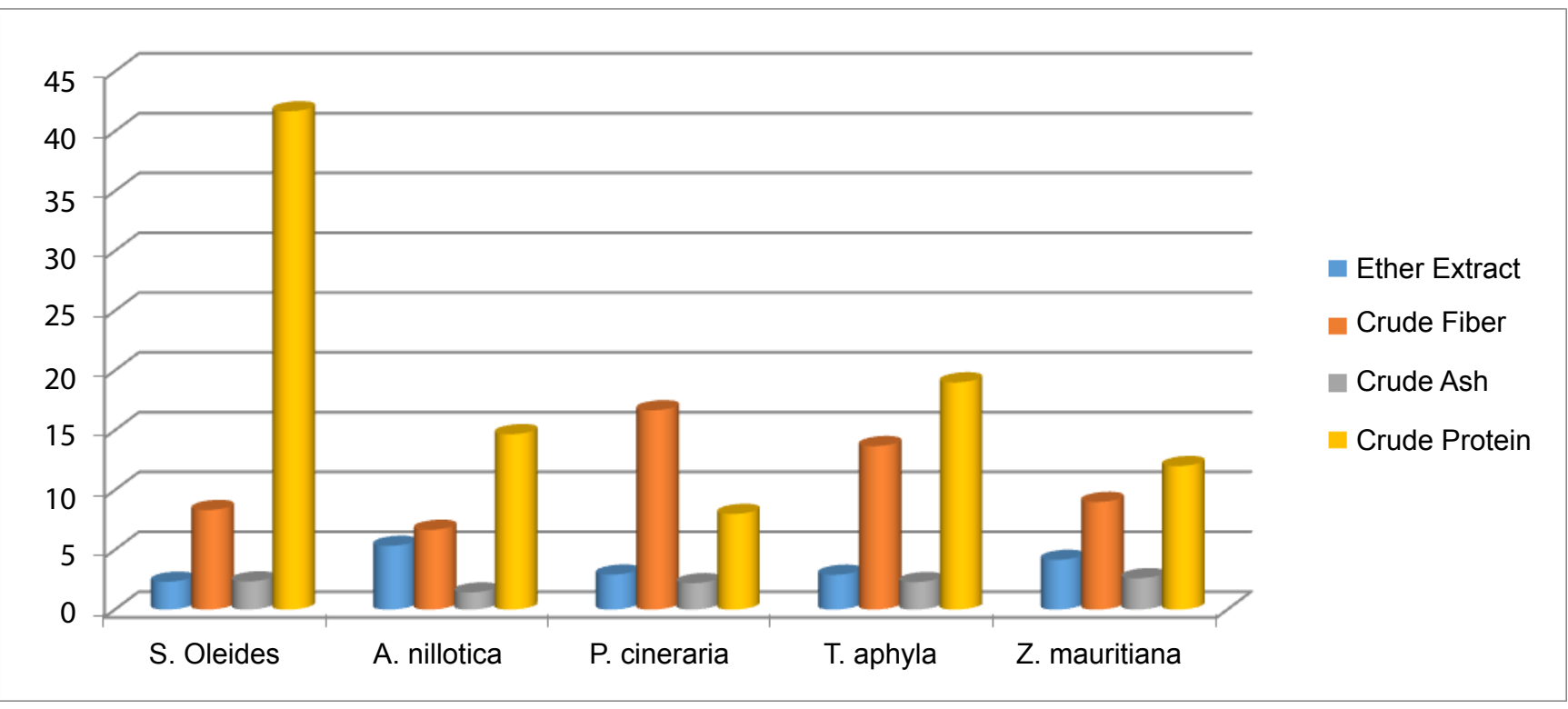

Figure 3: Proximate nutritional composition

(2.3\%), Prosopis cineraria (2.21\%) and lowest as $1.43 \%$ in Acacia nilotica. Five tree species were having a mean value of $2.184 \%$ of CP. Highest amount of CA was measured $41.67 \%$ in Salvadora oleiodes followed by Acacia nilotica (14.67\%), Tamarix aphylla (19\%), Zyziphus mauritiana (12\%) and least as eight percent in Prosopis cineraria. Mean value this CA was $19.068 \%$ (Table 2 and Figure 3 ).

\section{Discussion}

The present research on five multipurpose desert dwelling tree species of Cholistan desert was considered to find phytochemical composition and nutritive profile of these. The study is of great interest for pharmaceutical companies to develop and formulate new drugs to cure various diseases as the phytochemicals of these tree species are useful for curing and healing in different kind of viral and other type of diseases, of which the phenolic acids and flavonoids have gained more attention [40-42]. The curative properties of medicinal plants are due to the presence of various complex chemical substances of different composition which occur as secondary metabolites [43], grouped as alkaloids, glycosides, flavonoids, saponins, tannins and essential oils and this study resulted in account of flavonoids, saponins and alkaloids.

The leaves of Acacia nilotica have shown the presence of alkaloids, saponins, flavonoids but no steroid and finding is consistent with the results of Banso [44]. The extracts of Salvadora oleoides leaves showed the presence of alkaloids, saponin and flavonoids which is in line with the stem extract results $[45,46]$ but absence of steroids in our study showed dissimilarity.

The presence of phytochemicals in the leaves of Tamarix species justifies the local use of this plant for the treatment of various disorders. Current screening of the species resulted in the extraction of flavonoids, Saponins and alkaloids as the leaves are rich in flavonoids, saponins, polyphenols and proteins with considerable amount of carbohydrates and alkaloids [47] but my findings were in vain about the presence of steroids, detected earlier by Mohammedi et al. [48]. Our results about Zyziphus maritiana were same as that of Najafi's findings [49]. Thus the preliminary screening tests may be useful in the detection of the 
Citation: Hussain T, Rafay M, Manj IA, Ghazi MA, Rasool MA, et al. (2017) Desert Dwelling Trees: Forage Suitability and Ethnobotany, Pakistan. J Biodivers Endanger Species 5: 194. doi: 10.4172/2332-2543.1000194

Page 5 of 6

bioactive principles and subsequently may lead to the drug discovery and development.

Various phyto constituents like tannins (gallic acid), steroids (stigmasterol, campesterol, sitosterol, etc.), Flavone derivatives (prosogerin $\mathrm{A}, \mathrm{B}, \mathrm{C}, \mathrm{D}$, and $\mathrm{E}$ ), alkaloids (spicigerine, prosophylline), etc. isolated from the Prosopis cineraria pods by Rani et al. [50] correlates with this study on Prosopis cineraria. Different parts of the species are useful in treatment of skin diseases, piles, worms, vertigo and dyspnoea [51], protection from miscarriage, eye diseases, snake bite, asthma, bronchitis, dysentery, leucoderma, leprosy, muscle tremors and piles [19].

The nutritive profile of Acacia nilotica (EE: 5.33\%, CF: 6.67\%, CP: $1.43 \%$, CA: $14.67 \%$ \& NFE: $71.9 \%$ ) in this study satisfies the feeding needs of livestock in the most arid climatic area. Among all the highest ether extract value was recorded for A. nilotica means it contains the highest amount of energy than other species, the similarity as evoked by Sawe et al. [52]. Supplementation of A. nilotica (proanthocyanidins) is reported to be a potentially powerful nutritional approach for management of cardiovascular disease risk in individuals with both metabolic syndrome and elevated low density lipoprotein cholesterol [30].

Our results about Prosopis cineraria (EE: 2.92\%, CF: 16.67\%, CP: $2.21 \%$, CA: $8 \%$, NFE: $70.2 \%$ ) were compared with efforts of Rani et al. [50] that disclosed that green leaves of $P$. cineraria contain $14-18 \%$ crude protein, $13-22 \%$ crude fiber and about $6 \%$ ash, with a high calorific value of $5000 \mathrm{Kcal}$. Cheema et al. [53] explored the nutrational value of Morus alba, Acacia nilotica, Syzygium cumuni and Ziziphus jujuba leaves and stated that ash content (10\%) were higher in Z. jujuba and M. Alba, respectively and we recorded 12\% CA in Zyziphus mauritiana.

Lower crude protein content is found in Salvodora oleoides (2.36\%) leaves which are comparable with the results of Kajero et al. [54]. But local people use its fruit as food in the Cholistan desert as earlier described by Duhan et al. [55] that the fruits of Salvadora oleoides are a delicacy in rural areas, eaten locally, and have been found to be rich sources of calcium. This very useful species in restoration of the fragile arid tract and provides fodder and shelter to the wildlife and livestock, and fruit, medication and recreation to the inhabitants of the surrounding areas Duhan et al. [55].

\section{References}

1. Ahmed F, Urooj A (2009) Glucose-lowering, hepatoprotective and hypolipidemic activities of stem bark of Ficus racemosain streptozotocin-induced diabetic rats. $J$ Young Pharmacists 1: 160-164.

2. Cowan MM (1999) Plant products as antimicrobial agents. Clin Microbiol Rev 12: $564-582$.

3. Goyal M, Sharma SK (2009) Traditional wisdom and value addition prospects of arid foods of desert region of North West India. Indian Journal of Traditional Knowledge 8: 581-585.

4. Kumar R, Sharma RJ, Bairwa K, Roy RK, Kumar A (2010) Pharmacological review on natural antidiarrhoel agents. Der Pharma Chemica 2: 66-93.

5. Vidyadhar S, Saidulu M, Gopal TK, Chamundeeswari D, Rao U, Banji D(2010) In vitro anthelmintic activity of the whole plant of Enicostemmalittorale by using various extracts. Int J Appl Biol Pharma Tech 1: 1119-1125.

6. Argal A, Pathak AK (2006) CNS activity of Calotropisgigantea roots. J Ethnopharmacol 106: 142-145.

7. Nawwar MAM, Hussein SAM, Ayoub NA, Hofmann K, Linscheid M, et al. (2009) Aphyllin, the first isoferulic acid glycoside and other phenolics from Tamarix aphylla flowers. Pharmazie 64: 342-347.

8. Malik HMA (2001) Treatment through Herbs. In: Medicinal Plants of Pakistan, (Eds.): Anwar R, Haq N, Masood S pp: 21-23.
9. Qureshi R (2004) Floristic and ethnobotanical study of Desert-Nara Region sindh. Shah Abdul Latif University, Pakistan Research Repository pp: 1-454.

10. Malik A, Kalidhar SB (2007) Phytochemical examination of Prosopis cineraria L. (Druce) leaves. Indian J Pharm Sci 69: 576-578.

11. Trease GE, Evans WC (2002) Pharmacognosy (15 th Edn.), WB Saunders Company Ltd, London pp: 30.

12. Ghazanfar SA (1994) Handbook of Arabian Medicinal Plants, CRC. Press, Boca Roton, Ann Arbor, London, Tokyo, pp: 203.

13. Kamal M, Wazir SM, Hasan M, Khan SU, Subhan M, et al. (2009) Ethnobotanically important plants of district Bannu, Pakistan. Pak J PI Sci 15: 87-93.

14. Marwat SK, Khan MA, Ahmad M, Zafar M, Rehman F, et al. (2009) Salvadora persica, Tamarixaphylla and Zizyphus mauritianathree woody plant species mentioned in the Holy Qura'n and Ahadith and their ethnomedicinal uses in north-western part (D.I. Khan) of Pakistan. Pak J Nutr 8: 542-547.

15. Panhwar AQ, Abro H (2007) Ethnobotanical Studies of Mahal Kohistan (Khirthar national Park).Pak J Bot 39: 2301-2315.

16. Rahman MA, Haque E, Hassanuzzan M, Shahid IZ 2011) Antinociceptive anti-inflammatory and antibacterial properties of Tamarix indica roots. Int J Pharmacol 7: 527-531.

17. Bhattacharjee SK (2001) Handbook of Medicinal Plants, Edition 3, Pointer publication, Jaipur pp: 284.

18. Manikandar RVM, Rajesh V, Kumar RS, Perumal P, Raj CD (2011) Anthelmintic potential of Prosopis cineraria (Linn.) druce stem barks. J Pharm Res 2: 660662.

19. Velioglu YS, Mazza G, Gao L, Oomah BD (1998) Antioxidant Activity and Total Phenolics in Selected Fruits, Vegetables and Grain Products. J Agric Food Chem 46: 4113-4117.

20. McNeill DM, Osborne N, Osborne N, Komolong MK, Nankervis D (1998) Condensed tannins in the genus Leucaena and their nutritional significance for ruminants. In: Proc Conf Leucaena: adaptation, availability and farming system, Hanoi, Vietnam pp: 205-214.

21. Arshad M, Rao, Rehman AU (1993) Plant genetic resources of Cholistan desert and their utilization", Cholistan Institute of Desert Studies, Islamia University Bahawalpur, Pakistan.

22. Khan FM (2009) Ethno-Veterinary medicinal usage of flora of greater CholistanDesert (Pakistan).Pakistan Vet J 29: 78.

23. Hardikar SA, Panchal NS, Pandey AN (2011) Growth, water status and nutrient accumulation of seedlings of Slavadoraoleoides (Decne.) in response to soil salinity. J Trop Ecol 52: 253-264.

24. Khan AU (1996) Appraisal of ethno-ecological incentives to promote conservation of Salvadora oleoides Decne: The case for creating a resource area. J Bio Conser 75: 187-190.

25. Khan A, Mehmood S, Khan R, Khan S (2013) Ecological, Taxonomical and Ethenobotanical Study of Wild Fruit Producing Xerophytes of District Bannu, Kpk. J Medic Plants Stud 1: 112-120

26. Del WE (2009) In vitro evaluation of peroxyl radical scavenging capacity of water extract of Acacia nilotica (L). Afr J Biotechnol 8: 1270-1272.

27. Gill LS (2009) Ethanomedicinal uses of plants in Nigeria. University of Benin Press, Benin City, Nigeria pp. 10-30.

28. Rahaman O (2010) A Review of Uses of Acacia nilotica (Booni) In Alternative Medicine. Sofowara EA 1986. The state of Medicinal Plant Research in Nigeria. Nigeria Society of Pharmacognosy, Univ press Ibadan pp: 13-65.

29. Hirosh T, Mitsuy TM, Tosiyasu JES, Ikuko K (2004) Effect of green tea on blood glucose levels and serum proteomics patterns in diabetic mice and on glucose metabolism in healthy humans. BMC Pharma 4: 18-30.

30. Lerman RH, Minich DM, Darland G, Lamb JJ, Chang J, et al. (2010) Subjects with elevated LDL cholesterol and metabolic syndrome benefit from supplementation with soy protein phytosterols, hops rho iso-alpha acids, and Acacia nilotica proanthocyanidins. J Clinic Lipidol 4: 59-68.

31. Ncube NS, Afolayan AJ, Okoh Al (2008) Assessment techniques of antimicrobial properties of natural compounds of plant origin: current methods and future trends. Afr J Biotechnol 7: 1797-1806. 
Citation: Hussain T, Rafay M, Manj IA, Ghazi MA, Rasool MA, et al. (2017) Desert Dwelling Trees: Forage Suitability and Ethnobotany, Pakistan. J Biodivers Endanger Species 5: 194. doi: 10.4172/2332-2543.1000194

32. Taylor JLS, T Rabe T, McGaw LJ, Jäger AK, van Staden J (2001) Towards the scientific validation of traditional medicinal plants. Plant Growth Regul 34: 23-37.

33. Sarwat S, Shinwari ZK, Ahmad N (2012) Screening of potential medicinal plants from district Swat specific for controlling women diseases. Pak J Bot 44: 11931198.

34. Tiwari P, Kumar B, Kaur M, Kaur G, Kaur H (2011) Phytochemical screening and Extraction: A Review. Int Ph Sci 1: 98-106.

35. Arshad M, Ashraf MY, Ahamad M, Zaman F (2007) Morpho-genetic variability potential of Cenchrus ciliaris L., from Cholistan desert, Pakistan. Pak J Bot 39: 1481- 1488.

36. Ali I, Chaudhry MS, Farooq U (2009) Camel rearing in Cholistan Desert of Pakistan. Pak Vet J 29: 85-92.

37. Arshad M, Hussan AU, Ashraf MY, Noureen S, Moazzam M (2008) Edaphic factors and distribution of vegetation in the Cholistan desert, Pakistan. Pak J Bot 40: 1923-1931.

38. Arshad M, Ashraf M, Arif N (2006) Morphological variability of Prosopis cineraria (L.)Druce, from the Cholistan desert, Pakistan. Genet Resour Crop Evol 53: 1589-1596.

39. Singh S, Naresh V, Sharma SK (2013) Antibacterial Activity of Stem Bark of Salvadora Oleoides Decne. Int J Pharmacog Phytochem Res 5: 76-78.

40. Wadood A, Ghufran M, Jamal SB, Naeem M, Khan A, et al. (2013) Phytochemical Analysis of Medicinal Plants Occurring in Local Area of Mardan. Biochem Anal Biochem. 2: 1-4

41. Nostro A, Germanò MP, D'angelo V, Marino A, Cannatelli MA (2000) Extraction methods and bioautography for evaluation of medicinal plant antimicrobial activity. Lett Appl Microbiol 30: 379-384.

42. Balasundram N, Sundram K, Samman S (2006) Phenolic compounds in plants and agri-industrial by-products: Antioxidant activity, occurrence, and potential uses. Food Chem 99: 191-203.

43. Karthikeyan A, Shanthi V, Nagasathaya A (2009) Preliminary phytochemical and antibacterial screening of crude extract of the leaf of Adhatodavasica. L. Int J Green Pharm (3): 78-80.
44. Banso A (2009) Phytochemical and antibacterial investigatin of bark extracts of Acacia nilotica. J Med Plants Res 3: 082-085.

45. Arora M, Siddiqui AA, Paliwal S, Mishra R (2013) Pharmacognostical and Phytochemical investigation of Salvadora oleoidesDecne. stem. Int J Pharm Pharm Sci 5: 128-130.

46. Natubhai PM, Pandya SS, Rabari HA (2012) Preliminary phytochemical screening of Salvadora oleoides Decne (Salvadoraceae). Int J Pharm \& Life Sci pp: $2200-2205$.

47. Nizamani RA, Khan SA, Awan MS, Khan MM, Khan MT (2014) Nutritive Evaluation of Acacia nilotica indica forage for growing kids. J Anim \& Plant Sci 24: 55-58.

48. Mohammedi Z, Atik F (2011) Impact of solvent extraction type on total polyphenols content and biological activity from Tamarix aphylla (I.) Karst. Int J Pharma \& Bio Sci 2: 609-615.

49. Najafi S (2013) Phytochemical screening and antibacterial activity of leaf Extract of Ziziphus mauritianaLam. Int Res J Appl Basic Sci 4: 3274-3276.

50. Rani B, Singh U, Sharma R, Gupta A, Dhawan NG, et al. (2012) Prosopis cineraria (L) Druce: A desert tree to brace livelihood in Rajasthan. Asian $\mathrm{J}$ Pharmaceut Res Health Care 5: 58-64.

51. Manikandar RVM, Rajesh V, Kumar RS, Perumal P, Raj CD (2009) Analgesic and anti -pyretic activity of stem bark of Prosopis cineraria (Linn) Druce. J Pharm Res 2: 660-662.

52. Sawe JJ, Tuitoek JK, Ottaro JM (1998) Evaluation of common Tree leaves or pods as Supplements for Goats on Range Area of Kenya. Small Ruminant Res 28: 31-37.

53. Cheema UB, Sultan JI, Javaid A, Akhtar P, Shahid M (2011) Chemical composition, mineral profile and in situ digestion kinetics of fodder leaves of four native trees. Pak J Bot 43: 397-404.

54. Korejo F, Ali SA, Tahir SS, Rajput MT, Akhter MT (2010) Comparative morphological and biochemicalstudies of salvadora species foundin sindh, Pakistan. Pak J Bot 42: 1451-1463.

55. Duhan A, Chauhan B, Punia D(1992) Nutritional value of some non-conventional plant foods of India. Plant Foods for Human Nutrition 42: 193-200. 